\title{
References
}

\section{List of interviews}

\section{Brussels}

Interview BR 27, official from the EC 2, Brussels, 30 January 2018. Interview BR 28, official from the EC 1, Brussels, 30 January 2018. Interview BR 29, official from the EC 3, Brussels, 30 January 2018. Interview BR 32, official from the IMF, Athens, 5 February 2018. Interview BR 33, political advisor, phone call, 9 February 2018. Interview BR 35, official from the IMF, Skype call, 16 March 2018. Interview BR 53, official from the ECB, Skype call, 30 May 2018.

\section{Cyprus}

Interview CY 37, senior official at the Central Bank of Cyprus, Skype call, 26 March 2018.

Interview CY 40, senior officer at Central Bank of Cyprus, Nicosia, 10 April 2018. Interview CY 41, government official, Nicosia, 11 April 2018.

Interview CY 42, Minister, Nicosia, 11 April 2018.

Interview CY 43, journalist, Nicosia, 11 April 2018.

Interview CY 44, government official, Nicosia, 12 April 2018.

Interview CY 45, Minister, Nicosia, 12 April 2018.

Interview CY 46, trade union representative, Nicosia, 12 April 2018.

Interview CY 47, government official, Nicosia, 13 April 2018.

Interview CY 48, Minister, Nicosia, 13 April 2018.

Interview CY 49, Minister, Limassol, 13 April 2018.

Interview CY 50, government official, Nicosia, 13 April 2018.

Interview CY 55, Minister, Athens, 31 May 2018.

\section{Greece}

Interview GR 1, political advisor to Minister, Athens, 27 November 2017. Interview GR 3, Minister, Athens, 28 November 2017. 
Interview GR 4, Minister, Athens, 30 November 2017.

Interview GR 7, Minister, Athens, 1 December 2017.

Interview GR 8, Minister, Athens, 4 December 2017.

Interview GR 9, political advisor to Minister, Athens, 4 December 2017.

Interview GR 14, Member of Parliament and Minister, Athens, 7 December 2017.

Interview GR 15, Minister, Athens, 13 December 2017.

Interview GR 16, journalist, Athens, 13 December 2017.

Interview GR 17, political advisor, Athens, 15 December 2017.

Interview GR 18, political advisor, Athens, 18 December 2017.

Interview GR 20, Minister, Athens, 5 January 2018.

Interview GR 23, Secretary of State, Athens, 11 January 2018.

Interview GR 24, government official, Athens, 16 January 2018.

Interview GR 25, Minister, Athens, 19 January 2018.

Interview GR 31, Secretary of State, Athens, 2 February 2018.

Interview GR 34, Minister, Athens, 27 February 2018.

Interview GR 36, Minister, Athens, 21 March 2018.

Interview GR 51, Minister, Athens, 23 April 2018.

Interview GR 52, Member of Parliament, Athens, 26 May 2018.

Interview GR 54, Minister, 31 May 2018.

Interview GR 56, Member of Parliament and political and economic advisor, Athens, 19 June 2018.

\section{Ireland}

Interview IR 2, senior civil servant, Dublin, 16 January 2017.

Interview IR 3, civil servant, Dublin, 16 January 2017.

Interview IR 4, high official, Dublin, 18 January 2017.

Interview IR 5, trade union representative, Dublin, 18 January 2017.

Interview IR 6, party leader, Dublin, 19 January 2017.

Interview IR 7, trade union representative, Dublin, 19 January 2017.

Interview IR 8, senior civil servant, Dublin, 20 January 2017.

Interview IR 10, senior civil servant, Dublin, 15 January 2019.

Interview IR 11, Minister, Dublin, 15 January 2019.

Interview IR 12, Minister, Dublin, 16 January 2019.

Interview IR 13, Minister, Dublin, 16 January 2019.

Interview IR 14, senior civil servant, Dublin, 16 January 2019.

Interview IR 15, Minister, Dublin, 17 January 2019.

\section{Portugal}

Interview PT 1, Minister, Lisbon, 22 January 2013.

Interview PT 3, Minister, Lisbon, 17 January 2013.

Interview PT 4, Minister, Lisbon, 22 January 2013.

Interview PT 5, Minister, Lisbon, 17 January 2013.

Interview PT 6, Secretary of State, Lisbon, 28 January 2013. 
Interview PT 7, Secretary of State, Lisbon, 29 January 2013. Interview PT 8, Secretary of State, Lisbon, 29 January 2013. Interview PT 9, Secretary of State, Lisbon, 30 January 2013. Interview PT 10, Minister, Lisbon, 26 February 2013. Interview PT 11, Minister, Lisbon, 5 February 2013. Interview PT 12, Secretary of State, Lisbon, 11 December 2017. Interview PT 13, Secretary of State, Lisbon, 18 January 2018. Interview PT 14, Secretary of State, Lisbon, 25 January 2013. Interview PT 15, Secretary of State, Lisbon, 25 January 2018. Interview PT 16, Minister, Lisbon, 13 December 2017.

Interview PT 17, Secretary of State, Lisbon, 13 December 2017. Interview PT 18, Secretary of State, Lisbon, 14 December 2017. Interview PT 19, Secretary of State, Lisbon, 15 December 2017. Interview PT 20, Secretary of State, Lisbon, 11 December 2017. Interview PT 21, Secretary of State, Lisbon, 12 December 2017. Interview PT 23, trade union official, Lisbon, 18 December 2017. Interview PT 24, trade union official, Lisbon, 19 December 2017. Interview PT 27, IMF official, Lisbon, 15 February 2013.

Interview PT 28, official from the European Commission, Lisbon, 22 February 2013. Interview PT 29, official from the European Commission, Brussels, 22 February 2013. Interview PT 30, official from the European Commission, Brussels, 22 February 2013.

\section{Spain}

Interview ES 3, trade union official, Madrid, 18 November 2015. Interview ES 5, political advisor, Madrid,14 February 2016. Interview ES 6, Minister, Barcelona, 16 February 2016. Interview ES 7, Minister, Madrid, 25 February 2016. Interview ES 8, political advisor, Madrid, 26 February 2016. Interview ES 10, government official, Madrid, 20 November 2017. Interview ES 11, MP, Madrid, 20 November 2017. Interview ES 12, MP, Madrid, 21 November 2017. Interview ES 13, MP, Madrid, 21 November 2017. Interview ES 19, government official, Madrid, 23 November 2017. Interview ES 23, political party representative, Madrid, 10 October 2018. Interview ES 25, Cabinet Director, Madrid, 11 October 2018. Interview ES 26, Secretary of State, phone interview, 30 October 2019.

\section{Secondary sources}

AAP (2011), 'Austerity-hit Ireland is poster boy for EU', News.Com.Au, 27 November, available at: www.news.com.au/finance/austerity-hit-ireland-is-poster-boy-for-eu/ news-story/35cd3c259ffe99c02f308724d566114e (accessed 12 April 2019). 
Accornero, G. and Ramos Pinto, P. (2015), “"Mild mannered”? Protest and mobilisation in Portugal under austerity, 2010-2013', West European Politics, Vol. 38, No. 3, pp. 491-515.

Afflatet, N. (2016), 'Public debt and borrowing: are governments disciplined by financial markets?', Cogent Economics and Finance, Vol. 4, No. 1, pp. 1-14.

Afonso, A. (2019), 'State-led wage devaluation in Southern Europe in the wake of the Eurozone crisis', European Journal of Political Research, Vol. 58, No. 3, pp. 938-959.

Afonso, A. and Bulfone, F. (2019), 'Electoral coalitions and policy reversals in Portugal and Italy in the aftermath of the Eurozone crisis', South European Society and Politics, Vol. 24, No. 2, pp. 233-257.

Afonso, A., Zartaloudis, S. and Papadopoulos, Y. (2015), 'How party linkages shape austerity politics: clientelism and fiscal adjustment in Greece and Portugal during the Eurozone crisis', Journal of European Public Policy, Vol. 22, No. 3, pp. 315-334.

Aguiar, N. (2017), 'Bruxelas já não acha que subida do salário mínimo prejudica a competitividade', Jornal de Negócios, 25 May, available at: https:// rr.sapo.pt/2018/04/08/conversas-cruzadas/cativacoes-transformam-oe-em-gravefarsa-diz-luis-aguiar-conraria/artigo/110197/ (accessed 14 March 2020).

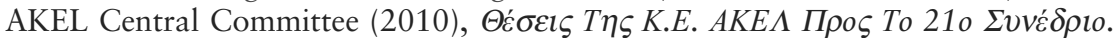

Alcaraz, C., Claessens, S., Cuadra, G., Marques-Ibanez, D. and Sapriza, H. (2019), 'Whatever it takes: what's the impact of a major nonconventional monetary policy intervention?', European Central Bank Working Paper Series, BIS Working Paper, No. 02249.

Alexiadou, D. and Gunaydin, H. (2019), 'Commitment or expertise? Technocratic appointments as political responses to economic crises', European Journal of Political Research, Vol. 58, No. 3, pp. 845-865.

Allan, J.P. and Scruggs, L. (2004), 'Political partisanship and welfare state reform in advanced industrial societies', American Journal of Political Science, Vol. 48, No. 3, pp. 496-512.

Allen, K. (2012), 'Recession and the new resistance', Irish Marxist Review, Vol. 1, No. 2, pp. 3-12.

Altman, D. and Pérez-Liñán, A. (2002), 'Assessing the quality of democracy: freedom, competitiveness and participation in eighteen Latin American countries', Democratization, Vol. 9, No. 2, pp. 85-100.

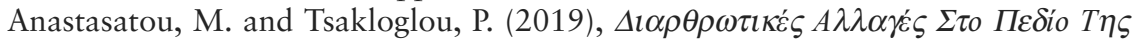

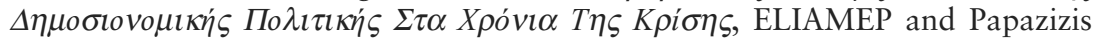
Publishers, Athens.

Armingeon, K. (2012), 'The politics of fiscal responses to the crisis of 2008-2009', Governance, Vol. 25, No. 4, pp. 543-565.

Arnold, M. (2020), 'Christine Lagarde apologises for botched communication of ECB strategy', Financial Times, 15 March, available at: www.ft.com/content/ ce39716e-66c0-11ea-a3c9-1fe6fedcca75 (accessed 27 April 2020).

Asensio, M. and Popic, T. (2019), 'Portuguese healthcare reforms in the context of crisis: external pressure or domestic choice?', Social Policy and Administration, Vol. 53, No. 7, pp. 1003-1017.

Badell, D., Di Mascio, F., Natalini, A., Ongaro, E., Stolfi, F. and Ysa, T. (2019), 'Too big to fail? The dynamics of EU influence and fiscal consolidation in Italy and Spain (2008-2016)', Public Management Review, Vol. 21, No. 9, pp. 1307-1329. 
Baerg, N.R. and Hallerberg, M. (2016), 'Explaining instability in the stability and growth pact: the contribution of member state power and euroskepticism to the euro crisis', Comparative Political Studies, Vol. 49, No. 7, pp. 968-1009.

Banco de España (2011), La Reestructuración Del Sector Bancario Español y El Real Decreto-Ley Para El Reforzamiento Del Sistema Financiero, Banco de España.

Banco de España (2012), Informe Anual 2012, Banco de España.

Bank of Greece (2014), The Chronicle of the Great Crisis, Bank of Greece, Athens.

Barber, T. (2009), 'Greece vows action to cut budget deficit', Financial Times, 20 October.

Barkbu, B., Eichengreen, B. and Mody, A. (2016), 'The euro's twin challenges: political and economic dynamics of the Eurozone crisis', in Caporaso, J. and Rhodes, M. (eds), The Political and Economic Dynamics of the Eurozone Crisis, Oxford University Press, Oxford, pp. 48-79.

Bastasin, C. (2009), 'Partisan protectionism: political consensus, the euro and Europe's response to the global crisis', in Micossi, S. and Tosato, G.L. (eds), The European Union in the 21st Century: Perspectives from the Lisbon Treaty, Centre for European Policy Studies, Brussels, pp. 7-30.

Bastos, J. (2018), “Cativações transformam OE em grave farsa”, diz Luís AguiarConraria', Rádio Renascença, 8 April, available at: https://rr.sapo.pt/2018/04/08/ conversas-cruzadas/cativacoes-transformam-oe-em-grave-farsa-diz-luis-aguiarconraria/artigo/110197/ (accessed 20 December 2019).

Bauer, M.W. and Becker, S. (2014), 'The unexpected winner of the crisis: the European Commission's strengthened role in economic governance', Journal of European Integration, Vol. 36, No. 3, pp. 213-229.

BBC (2012), 'Spain to miss 2012 budget deficit target, says Rajoy', BBC, 2 March, available at: www.bbc.com/news/business-17235179 (accessed 10 March 2020).

BBC (2019), 'Greek government crisis over Macedonia name change', BBC, 13 January, available at: www.bbc.co.uk/news/world-europe-46855088 (accessed 10 February 2020).

Beyers, J., Braun, C. and Klüver, H. (2017), 'Framing between the logic of membership and the logic of influence', in Beyers, J., Braun, C. and Klüver, H. (eds), Legislative Lobbying in Context: The Policy and Polity Determinants of Interest Group Politics in the European Union, Routledge, Abingdon and New York, pp. 50-52.

Bird, G. and Willett, T.D. (2004), 'IMF conditionality, implementation and the new political economy of ownership', Comparative Economic Studies, Vol. 46, No. 3, pp. 423-450.

Blanchard, O. and Leigh, D. (2013), Growth Forecast Errors and Fiscal Multipliers, IMF Working Paper No. WP/13/1, International Monetary Fund.

Blustein, P. (2016), Laid Low: Inside the Crisis That Overwhelmed Europe and the $I M F$, Centre for International Governance Innovation, Waterloo.

Blyth, M. (2013), Austerity: The History of a Dangerous Idea, Oxford University Press, New York.

Bonoli, G. and Natali, D. (2012), The Politics of the New Welfare State, Oxford University Press, Oxford.

Börzel, T. and Risse, T. (2003), 'Conceptualizing the domestic impact of Europe', in Featherstone, K. and Radaelli, C. (eds), The Politics of Europeanisation, Oxford University Press, Oxford, pp. 57-80.

Börzel, T.A. and Risse, T. (2009), The Transformative Power of Europe: The European Union and the Diffusion of Ideas, Vol. 1, Freie Universität Berlin, FB Politik- und Sozialwissenschaften, Otto-Suhr-Institut für Politikwissenschaft 
Kolleg-Forschergruppe 'The Transformative Power of Europe', Berlin, available at: https://nbn-resolving.org/urn:nbn:de:0168-ssoar-364733 (accessed 15 July 2019).

Bosco, A. (2013), 'The long adiós: the PSOE and the end of the Zapatero era', in Field, B. and Botti, A. (eds), Politics and Society in Contemporary Spain, Palgrave Macmillan, New York, pp. 21-39.

Bosco, A. and Verney, S. (2012), 'Electoral epidemic: the political cost of economic crisis in Southern Europe, 2010-11', South European Society and Politics, Vol. 17, No. 2, pp. 129-154.

Bosco, A. and Verney, S. (2016), 'From electoral epidemic to government epidemic: the next level of the crisis in Southern Europe', South European Society and Politics, Vol. 21, No. 4, pp. 383-406.

Botti, A. (2013), 'From opposition to government: the Popular Party of Mariano Rajoy', in Field, B. and Botti, A. (eds), Politics and Society in Contemporary Spain, Palgrave Macmillan, New York, pp. 41-59.

Boyle, R. (2016), 'Public sector reform', in Roche, W.K., O'Connell, P.J. and Prothero, A. (eds), Austerity and Recovery in Ireland: Europe's Poster Child and the Great Recession, Oxford University Press, Oxford, pp. 214-231.

Branco, R., Cardoso, D., Guillén, A.M., Sacchi, S. and Balbona, D.L. (2019), 'Here to stay? Reversals of structural reforms in Southern Europe as the crisis wanes', South European Society and Politics, Vol. 24, No. 2, pp. 205-232.

Brazys, S. and Hardiman, N. (2015), 'From "Tiger" to "PIIGS": Ireland and the use of heuristics in comparative political economy', European Journal of Political Research, Vol. 54, No. 1, pp. 23-42.

Bremer, B. (2018), 'The missing Left? Economic crisis and the programmatic response of social democratic parties in Europe', Party Politics, Vol. 24, No. 1, pp. 23-38.

Bulmer, S. (2014), 'Germany and the Eurozone crisis: between hegemony and domestic politics', West European Politics, Vol. 37, No. 6, pp. 1244-1263.

Buthe, T., Jacobs, A.M., Bleich, E., Pekkanen, R., Trachtenberg, M., Cramer, K., Shih, V., et al. (2015), 'Transparency in qualitative and multi-method research: a symposium', Qualitative and Multi-method Research: Newsletter of the American Political Science Association's QMMR Section, Vol. 13, No. 1, pp. 2-64.

Campos, N.F. and Horváth, R. (2012), 'Reform redux: measurement, determinants and growth implications', European Journal of Political Economy, Vol. 28, No. 2, pp. 227-237.

Campos Lima, M. da P. and Artiles, A.M. (2011), 'Crisis and trade union challenges in Portugal and Spain: between general strikes and social pacts', Transfer: European Review of Labour and Research, Vol. 17, No. 3, pp. 387-402.

Capelos, T. and Exadaktylos, T. (2015), “"The good, the bad and the ugly”: stereotypes, prejudices and emotions on Greek media representation of the EU financial crisis', in Karyotis, G. and Gerodimos, R. (eds), The Politics of Extreme Austerity: Greece in the Eurozone Crisis, Palgrave Macmillan, London, pp. 46-68.

Caporaso, J. and Rhodes, M. (2016), 'Introduction', in Caporaso, J. and Rhodes, M. (eds), The Political and Economic Dynamics of the Eurozone Crisis, Oxford University Press, Oxford, pp. 1-15.

Cardiff, K. (2019), 'Ireland: back to a different normal', in Chang, M., Steinberg, F. and Torres, F. (eds), The Political Economy of Adjustment Throughout and Beyond the Eurozone, Routledge, Abingdon, pp. 94-121.

Cardoso, D. and Branco, R. (2018), 'Liberalised dualisation: labour market reforms and the crisis in Portugal: a new departure', European Journal of Social Security, Vol. 20, No. 1, pp. 31-48. 
Chang, M., Steinberg, F. and Torres, F. (eds) (2019), The Political Economy of Adjustment Throughout and Beyond the Eurozone Crisis: What Have We Learned?, Routledge, Abingdon and New York.

Charalambous, G. (2014), Political Culture and Behaviour in the Republic of Cyprus during the Crisis, PCC Report No. 2/2014, Peace Research Institute Oslo, Oslo.

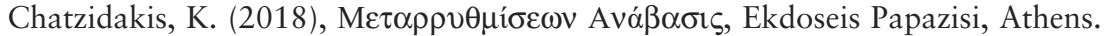

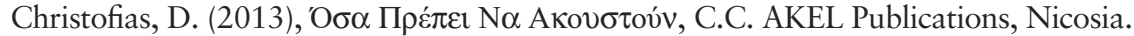

Chwieroth, J.M. (2015), 'Professional ties that bind: how normative orientations shape IMF conditionality', Review of International Political Economy, Vol. 22, No. 4, pp. 757-787.

Cioffi, J.W. and Dubin, K.A. (2016), 'Commandeering crisis: partisan labor repression in Spain under the guise of economic reform', Politics and Society, Vol. 44, No. 3, pp. 423-453.

Clauwaert, S. and Schömann, I. (2012), 'The crisis and national labour law reforms: a mapping exercise', European Labour Law Journal, Vol. 3, No. 1, pp. 54-69.

Clerides, S. (2014), 'The collapse of the Cypriot banking system: a bird's eye view', Cyprus Economic Policy Review, Vol. 8, No. 2, pp. 3-35.

Clift, B. (2018), The IMF and the Politics of Austerity in the Wake of the Global Financial Crisis, Oxford University Press, Oxford.

Clift, B. and Ryner, M. (2014), 'Joined at the hip, but pulling apart? Franco-German relations, the Eurozone crisis and the politics of austerity', French Politics, Vol. 12, No. 2, pp. 136-163.

Clifton, J., Diaz-Fuentes, D. and Gómez, A.L. (2018), 'The crisis as opportunity? On the role of the Troika in constructing the European consolidation state', Cambridge Journal of Regions, Economy and Society, Vol. 11, No. 3, pp. 587-608.

Cline, W.R. and Wolf, G.B. (eds) (2012), Resolving the European Debt Crisis, Vol. 21, Peterson Institute for International Economics, Bruegel.

Coller, X. and de Luis, F.R. (2020), 'Unstable preferences and policy changes: Spain', in Morlino, L. and Sottilotta, C. (eds), The Politics of the Eurozone Crisis in Southern Europe, Palgrave Macmillan, Cham, pp. 133-171.

Collier, D. (2011), 'Understanding process tracing', PS: Political Science \& Politics, Vol. 44, No. 4, pp. 823-830.

Comisiones Obreras (2016), CCOO y UGT Exigen al Gobierno Que Cumpla Los Compromisos Del Programa de Activación Para El Empleo, Comisiones Obreras, available at https:/www.ccoo.es/noticia:125544-CCOO_y_UGT_exigen_ al_Gobierno_que_cumpla_los_compromisos_del_Programa_de_Activacion_para_ el_Empleo (accessed 15 July 2019).

Comissão Permanente da Concertação Social (2012), Agreement for Growth, Competitiveness and Employment, CES, Lisbon.

Commission Toledo Pact (2010), Informe de Evaluación y Reforma Del Pacto de Toledo, Spanish Parliament, Spain.

Considine, M. and Dukelow, F. (2014), 'The role of national and international policy actors and influences in the crisis: the case of Ireland', in Hill, M. (ed.), Studying Public Policy: An International Approach, Policy Press, Bristol, pp. 254-266.

Copelovitch, M., Frieden, J. and Walter, S. (2016), 'The political economy of the Euro crisis', Comparative Political Studies, Vol. 49, No. 7, pp. 811-840.

Copelovitch, M.S. (2010), 'Master or servant? Common agency and the political economy of IMF lending', International Studies Quarterly, Vol. 54, No. 1, pp. 49-77. 
Council of the European Union (2008), Presidency Conclusions, Council of the European Union, Brussels.

Council of the European Union (2009), Economic and Finance Affairs, Council of the European Union, Brussels.

Council of the European Union (2010a), Press Release: Extraordinary Council Meeting Economic and Financial Affairs Brussels.

Council of the European Union (2010b), Council Decision of 13 July 2010 on the Existence of an Excessive Deficit in Cyprus, No. 2010/401/EU.

Council of the European Union (2011), Council Recommendation of 12 July 2011 on the National Reform Programme 2011 of Spain and Delivering a Council Opinion on the Updated Stability Programme of Spain, 2011-2014.

Crespy, A. and Ladi, S. (2019), 'In the name of "the people"? Popular sovereignty and the 2015 Greek referendum', Journal of European Integration, Vol. 41, No. 7, pp. 871-885.

Cué, C. (2011), 'Rajoy aprueba el mayor recorte de la historia y una gran subida de impuestos', El País, 31 December.

Cukierman, A. and Tommasi, M. (1998), 'When does it take a Nixon to go to China?', American Economic Review, Vol. 88, No. 1, pp. 180-197.

Cusack, T., Iversen, T. and Rehm, P. (2006), 'Risks at work: the demand and supply sides of government redistribution', Oxford Review of Economic Policy, Vol. 22, No. 3, pp. 365-389.

D’Arcy, M. (2018), Pay Inequality in the Public Service: Statements, Dáil Éireann debate, 24 May.

Davis, M. (2016), 'Social democracy's last rounds: an interview with Wolfgang Streeck', Jacobin, February, available at: www.jacobinmag.com/2016/02/wolfgangstreeck-europe-eurozone-austerity-neoliberalism-social-democracy/ (accessed 1 March 2021).

De Giorgi, E. and Cancela, J. (2019), 'The Portuguese radical left parties supporting government: from policy-takers to policymakers?', Government and Opposition, pp. $1-20$.

De Giorgi, E., Moury, C. and Ruivo, J.P. (2015), 'Incumbents, opposition and international lenders: governing Portugal in times of crisis', Journal of Legislative Studies, Vol. 21, No. 1, pp. 54-74.

De Grauwe, P. (2010), 'Fighting the wrong enemy, 19 May 2010', VOX CEPR Policy Portal, 19 May, available at: https://voxeu.org/article/europe-s-privateversus-public-debt-problem-fighting-wrong-enemy (accessed 1 March 2021).

De Grauwe, P. (2011), Only a More Active ECB Can Solve the Euro Crisis, Centre for European Policy Studies Policy Briefs No. 250.

De Grauwe, P. (2012), 'The governance of a fragile Eurozone', Australian Economic Review, Vol. 45, No. 3, pp. 255-268.

De Guindos, L. (2016), España Amenazada: De Cómo Evitamos El Rescate y La Economía Recuperó El Crecimiento, Ediciones Península, Madrid.

De la Porte, C. and Natali, D. (2014), 'Altered Europeanisation of pension reform in the context of the great recession: Denmark and Italy compared', West European Politics, Vol. 37, No. 4, pp. 732-749.

De Witte, B. (2009), 'The Lisbon Treaty and national constitutions: more or less Europeanisation?', in Closa, C. (ed.), The Lisbon Treaty and National Constitutions: Europeanisation and Democratic Implications, ARENA, Oslo, pp. 25-48.

Degryse, C. (2012), The New European Economic Governance, ETUI, Brussels. 
Del Pino, E. (2013), 'The Spanish welfare state from Zapatero to Rajoy: recalibration to retrenchment', in Field, B. and Botti, A. (eds), Politics and Society in Contemporary Spain, Palgrave Macmillan, New York, pp. 197-216.

Dellepiane, S. and Hardiman, N. (2012), 'The new politics of austerity: fiscal responses to the economic crisis in Ireland and Spain', University College Dublin, Geary Institute Discussion Paper.

Demertzis, M. and Wolff, G.B. (2016), The Effectiveness of the European Central Banks's Asset Purchase Programme, Bruegel Policy Contribution No. 2016/10, available at: http://hdl.handle.net/10419/165978 (accessed 11 October 2019).

Demetriades, P. (2017), Diary of the Euro Crisis in Cyprus, Palgrave Macmillan, Cham.

Dendrinou, V. and Varvitsioti, H. (2019), The Last Bluff: How Greece Came Face-to-Face with Financial Catastrophe and the Secret Plan for Its Euro Exit, Papadopoulos Publishing, Athens.

Diario de Avisos (2011), 'La UE aconseja a Zapatero que culmine con firmeza las reformas', Diario de Avisos, 5 August.

Dijsselbloem, J. (2018), H Kpíon Tov Evpó, Economia Publishing, Athens.

Dimitrakopoulos, D. and Passas, A. (2020), The Depoliticisation of Greece's Public Revenue Administration, Springer, Cham.

Dinas, E. and Rori, L. (2013), 'The 2012 Greek parliamentary elections: fear and loathing in the polls', West European Politics, Vol. 36, No. 1, pp. 270-282.

Dinis, D. and Coelho, H.F. (2012), Resgatados: Os Bastidores Da Ajuda Financeira a Portugal, Esfera dos Livros, Lisbon.

Doherty, M. (2011), 'It must have been love ... but it's over now: the crisis and collapse of social partnership in Ireland', Transfer: European Review of Labour and Research, Vol. 17, No. 3, pp. 371-385.

Doncel, L. (2012a), 'Europe braces itself for bailout dilemma: who gets the money?', El País, 3 June.

Doncel, L. (2012b), 'La Unión Europea anima a España al rescate financiero', El País, 3 June.

Dooley, N. (2019), 'Who's afraid of the big bad wolf? Rethinking the core and periphery in the Eurozone crisis', New Political Economy, Vol. 21, No. 4, pp. 62-88.

Doyle, D. (2012), 'Pressures to privatize? The IMF, globalization, and partisanship in Latin America', Political Research Quarterly, Vol. 65, No. 3, pp. 572-585.

Drazen, A. (2002), 'Conditionality and ownership in IMF Lending: a political economy Approach', IMF Staff Papers, Vol. 49, No. 1, pp. 36-67.

Dreher, A. (2004), 'A public choice perspective of IMF and World Bank lending and conditionality', Public Choice, Vol. 119, Nos 3-4, pp. 445-464.

Dukelow, F. (2015), “Pushing against an open door”: reinforcing the neo-liberal policy paradigm in Ireland and the impact of EU intrusion', Comparative European Politics, Vol. 13, No. 1, pp. 93-111.

Dür, A. and Mateo, G. (2010), 'Choosing a bargaining strategy in EU negotiations: power, preferences, and culture', Journal of European Public Policy, Vol. 17, No. 5, pp. 680-693.

Dyson, K. (1994), Elusive Union: The Process of Economic and Monetary Union in Europe, Longman, London.

Dyson, K. and Featherstone, K. (1996), 'Italy and EMU as a "Vincolo Esterno": empowering the technocrats, transforming the state', South European Society and Politics, Vol. 1, No. 2, pp. 272-299. 
ECOFIN (2009), Informal Meeting of Finance Ministers and Governors of Central Banks, ECOFIN, Prague.

El Confidencial (2018), 'El IVA del cine baja del 21 al 10 \% con la aprobación definitiva de los Presupuestos', El Confidencial, 28 June.

El Mundo (2010), 'Así queda la reforma laboral: despido más barato y mayor control a los parados', El Mundo, 10 September.

El País (2010), 'Cronología de las reformas laborales en España', El País, 15 June.

Elster, J. (1979), Ulysses and the Sirens: Studies in Rationality and Irrationality, Cambridge University Press, Cambridge.

Epstein, R.A. and Sedelmeier, U. (2008), 'Beyond conditionality: international institutions in postcommunist Europe after enlargement', Journal of European Public Policy, Vol. 15, No. 6, pp. 795-805.

Euractiv (2012), 'EU explores Spain bank rescue', Euractiv, 7 July.

Eurofound (2015), Ireland: New Public Sector Agreement Passed, Eurofound, Dublin.

Eurogroup (2012a), Eurogroup Statement 21/2/12, available at: https://www.consilium. europa.eu/media/25716/128075.pdf (accessed 1 March 2021).

Eurogroup (2012b), Eurogroup Statement 12/11/12, available at: www.consilium. europa.eu/media/24045/133445.pdf (accessed 1 March 2021).

Eurogroup (2012c), Eurogroup Statement 13/12/12, available at: www.consilium. europa.eu/media/24051/134270.pdf (accessed 1 March 2021).

Eurogroup (2012d), Eurogroup Statement 27/11/12, available at: www.consilium. europa.eu/media/24042/133857.pdf (accessed 1 March 2021).

Eurogroup (2012e), Eurogroup Statement on Spain, available at: www.consilium. europa.eu/media/25703/131309.pdf (accessed 1 March 2021).

Eurogroup (2013), Eurogroup Statement on Cyprus, available at: www.consilium. europa.eu/media/24039/135809.pdf (accessed 1 March 2021).

Eurogroup (2014), Eurogroup Supports a Two-Month Programme Extension for Greece, available at: www.consilium.europa.eu/en/meetings/eurogroup/2014/12/08/ (accessed 4 February 2020).

Eurogroup (2020), Report on the Comprehensive Economic Policy Response to the COVID-19 Pandemic, 9 April, available at: www.consilium.europa.eu/en/press/ press-releases/2020/04/09/report-on-the-comprehensive-economic-policy-responseto-the-covid-19-pandemicl (accessed 10 May 2020).

Euronews (2017), 'Spanish economy shows strong 2016 growth', available at: www.euronews.com/2017/01/30/spanish-economy-shows-strong-2016-growth (accessed 1 March 2021).

European Central Bank (2011), Letter to Mr. José Luis Rodríguez Zapatero, European Central Bank, Frankfurt and Madrid, available at: www.ecb.europa.eu/pub/pdf/ other/letter_mr_zapatero_es.pdf (accessed 1 March 2021).

European Central Bank (2015), Eligibility of Greek Bonds Used as Collateral in Eurosystem Monetary Policy Operations, 4 February, available at: www.ecb.europa.eu/ press/pr/date/2015/html/pr150204.en.html (accessed 4 February 2020).

European Commission (undated a), Financial Assistance to Greece, European Commission, Brussels, available at: https://ec.europa.eu/info/business-economyeuro/economic-and-fiscal-policy-coordination/eu-financial-assistance/ which-eu-countries-have-received-assistance/financial-assistance-greece_ en\#secondeconomicadjustmentprogrammeforgreece (accessed 4 February 2020).

European Commission (undated b), Deposit Guarantee Scheme, European Commission, Brussels, available at: https://ec.europa.eu/info/business-economy-euro/ banking-and-finance/financial-supervision-and-risk-management/managing- 
risks-banks-and-financial-institutions/deposit-guarantee-schemes_en (accessed 25 February 2020).

European Commission (2008a), State Aid: Frequently Asked Questions Concerning EU Rules, No. MEMO/08/660, European Commission, Brussels, available at: https://ec.europa.eu/commission/presscorner/detail/en/MEMO_08_660 (accessed 15 January 2019).

European Commission (2008b), Communication from the Commission to the European Council - A European Economic Recovery Plan, European Commission, Brussels.

European Commission (2009), Recommendation for a Council Recommendation to Spain with a View to Bringing an End to the Situation of an Excessive Government Deficit, European Commission, Brussels.

European Commission (2010a), Report on Greek Government Deficit and Debt Statistics, No. COM(2010) 1 final, European Commission, Brussels.

European Commission (2010b), Commission Assesses Stability Programme of Greece; Makes Recommendations to Correct the Excessive Budget Deficit, Improve Competitiveness through Structural Reforms and Provide Reliable Statistics, No. IP/10/116, European Commission, Brussels.

European Commission (2010c), The Economic Adjustment Programme for Greece, Occasional Papers No. 61, European Commission, Brussels.

European Commission (2010d), The Economic Adjustment Programme for Greece, First Review - Summer 2010, Occasional Papers No. 68, European Commission, Brussels.

European Commission (2010e), The Economic Adjustment Programme for Greece, Second Review - Autumn 2010, Occasional Papers No. 72, European Commission, Brussels.

European Commission (2010f), Communication from the Commission to the Council, European Commission, Brussels.

European Commission (2010g), Green Paper on Adequate, Sustainable and Safe European Pension Systems, European Commission, Brussels.

European Commission (2011a), The Economic Adjustment Programme for Greece, Fourth Review - Spring 2011, Occasional Papers No. 82, European Commission, Brussels.

European Commission (2011b), The Economic Adjustment Programme for Greece, Fourth Review - October 2011, Occasional Papers No. 87, European Commission, Brussels.

European Commission (2011c), The Economic Adjustment Programme for Ireland, Occasional Papers No. 76, European Commission, Brussels.

European Commission (2011d), Economic Adjustment Programme for Ireland Spring 2011 Review, Occasional Papers No. 78, European Commission, Brussels.

European Commission (2011e), Economic Adjustment Programme for Ireland Summer 2011 Review, Occasional Papers No. 84 REVIEW 3, European Commission, Brussels.

European Commission (2011f), Economic Adjustment Programme for Ireland Autumn 2011 Review, Occasional Papers No. 88 REVIEW 4, European Commission, Brussels.

European Commission (2012a), The Second Economic Adjustment Programme for Greece, Occasional Papers No. 94, European Commission, Brussels.

European Commission (2012b), Economic Adjustment Programme for Ireland Spring 2012 Review, Occasional Papers No. 96 REVIEW 6, European Commission, Brussels. 
European Commission (2012c), Economic Adjustment Programme for Ireland Autumn 2012 Review, Occasional Papers No. 127 REVIEW 8, European Commission, Brussels.

European Commission (2012d), Spain: Memorandum of Understanding on FinancialSector Policy Conditionality, European Commission, Brussels.

European Commission (2012e), Recommendation for a Council Recommendation on Spain's 2012 National Reform Programme and Delivering a Council Opinion on Spain's Stability Programme for 2012-2015, European Commission, Brussels.

European Commission (2013a), Economic Adjustment Programme for Ireland Spring 2013 Review, Occasional Papers No. 154 REVIEW 10, European Commission, Brussels.

European Commission (2013b), Economic Adjustment Programme for Ireland Autumn 2013 Review, Occasional Papers No. 167, European Commission, Brussels.

European Commission (2013c), Recommendation for a Council Recommendation on Spain's 2013 National Reform Programme and Delivering a Council Opinion on Spain's Stability Programme for 2012-2016, European Commission, Brussels.

European Commission (2013d), The Economic Adjustment Programme for Cyprus, Occasional Papers No. 149, European Commission, Brussels.

European Commission (2013e), The Economic Adjustment Programme for Cyprus First Review - Summer 2013, Occasional Papers No. 161, European Commission, Brussels.

European Commission (2013f), The Economic Adjustment Programme for Cyprus Second Review - Autumn 2013, Occasional Papers No. 169, European Commission, Brussels.

European Commission (2014a), The Economic Adjustment Programme for Cyprus Third Review - Winter 2014, Occasional Papers No. 189, European Commission, Brussels.

European Commission (2014b), The Economic Adjustment Programme for Cyprus Fourth Review - Spring 2014, Occasional Papers No. 197, European Commission, Brussels.

European Commission (2014c), The Economic Adjustment Programme for Cyprus Fifth Review - Summer 2014, Occasional Papers No. 209, European Commission, Brussels.

European Commission (2015a), Memorandum of Understanding Between the European Commission Acting on Behalf of the European Stability Mechanism, and the Hellenic Republic and the Bank of Greece, European Commission, Brussels.

European Commission (2015b), Ex Post Evaluation of the Economic Adjustment Programme Ireland: 2010-2013, European Economy Institutional Paper No. 004, European Commission, Brussels.

European Commission (2015c), The Economic Adjustment Programme for Cyprus Sixth Review - Spring 2015, Institutional Paper No. 004, European Commission, Brussels.

European Commission (2015d), The Economic Adjustment Programme for Cyprus Seventh Review - Summer 2015, Institutional Paper No. 009, European Commission, Brussels.

European Commission (2016a), Compliance Report: The Third Economic Adjustment Programme for Greece, First Review, European Commission, Brussels.

European Commission (2016b), Post-Programme Surveillance Report Ireland, Spring 2016, European Economy Institutional Paper No. 035, European Commission, Brussels. 
European Commission (2016c), Post-Programme Surveillance Report, Cyprus, Autumn 2016, Institutional Paper No. 042, European Commission, Brussels.

European Commission (2017a), Compliance Report: The Third Economic Adjustment Programme for Greece, Second Review, European Commission, Brussels.

European Commission (2017b), Post-Programme Surveillance Report, Cyprus, Spring 2017, Institutional Paper No. 058, European Commission, Brussels.

European Commission (2018a), Enhanced Surveillance Report, Greece, November 2018, Institutional Paper No. 090, European Commission, Brussels.

European Commission (2018b), European Semester: Country Report - Portugal, Country Report No. Portugal 2018, European Commission, Brussels.

European Commission (2019), Post-Programme Surveillance Report, Cyprus, Spring 2019, Institutional Paper No. 104, European Commission, Brussels.

European Council (2013), Proposal for a Council Opinion on the Economic Partnership Programme of Spain, European Council, Brussels.

European Council (2020), Report on the Comprehensive Economic Policy Response to the COVID-19 Pandemic, 9 April, available at: www.consilium.europa.eu/ en/press/press-releases/2020/04/09/report-on-the-comprehensive-economic-policyresponse-to-the-covid-19-pandemic/ (accessed 10 May 2020).

European Court of Auditors (2017), Special Report: The Commission's Intervention in the Greek Financial Crisis, Special report No. 17, Luxembourg, available at: www.consilium.europa.eu/en/meetings/eurogroup/2014/12/08/ (accessed 4 February 2020).

European Stability Mechanism (2016), Accessing sovereign markets - the Recent Experiences of Ireland, Portugal, Spain, and Cyprus, Discussion Paper, 2, June, available at: www.esm.europa.eu/publications/accessing-sovereign-markets-recentexperiences-ireland-portugal-spain-and-cyprus (accessed 1 March 2021).

European Stability Mechanism (2019), Safeguarding the Euro in Times of Crisis: The Inside Story of the ESM, Publications Office of the European Union, Luxembourg.

Ewing, J. (2012), 'Greek crisis leaves Cyprus mired in debt', New York Times, 11 April, available at: www.nytimes.com/2012/04/12/business/global/in-cyprusa-national-quest-to-shore-up-teetering-banks.html (accessed 24 February 2020).

Exadaktylos, T. and Zahariadis, N. (2014), 'Quid pro quo: political trust and policy implementation in Greece during the age of austerity', Politics and Policy, Vol. 42, No. 1, pp. 160-183.

Expansión (2012), 'Bruselas presiona: la reforma laboral en España es una prioridad urgente', Expansión, 10 January.

Expansión (2016), 'El Gobierno aprueba el recorte del gasto en 5.493 millones de euros para 2017', Expansión, 30 December.

Faria, R. and Aníbal, S. (2012), 'Chefe de missão do FMI: mudanças na TSU não foram exigência da Troika', Público, 12 September.

Featherstone, K. (2003), 'Greece and EMU: between external empowerment and domestic vulnerability', JCMS: Journal of Common Market Studies, Vol. 41, No. 5, pp. 923-940.

Featherstone, K. (2015), 'External conditionality and the debt crisis: the 'Troika'and public administration reform in Greece', Journal of European Public Policy, Vol. 22, No. 3, pp. 295-314.

Featherstone, K. and Papadimitriou, D. (2008), The Limits of Europeanization: Reform Capacity and Policy Conflict in Greece, Palgrave Macmillan, New York. 
Feld, L.P., Köhler, E.A. and Nientiedt, D. (2015), 'Ordoliberalism, pragmatism and the eurozone crisis: how the German tradition shaped economic policy in Europe', European Review of International Studies, Vol. 2, No. 3, pp. 48-61.

Fernandes, J.M. and Jalali, C. (2017), 'A resurgent presidency? Portuguese semipresidentialism and the 2016 elections', South European Society and Politics, Vol. 22, No. 1, pp. 121-138.

Fernandes, J.M., Magalhães, P.C. and Santana-Pereira, J. (2018), 'Portugal's leftist government: from sick man to poster boy?', South European Society and Politics, Vol. 23, No. 4, pp. 503-524.

Ferrándiz, J.P. and Lobera, J. (2019), 'Estimación electoral en tiempos de multipartidismo: comparación de indicadores en cuatro elecciones generales (2015-2019)', Panorama Social, Fundación de las Cajas de Ahorros (FUNCAS), No. 30, pp. 55-68.

Ferreira, C. (2012), 'O dia em que Sócrates pediu a Cavaco para o salvar da troika', Público, 17 May, available at: www.publico.pt/2012/05/17/politica/noticia/o-di a-em-que-socrates-pediu-a-cavaco-para-o-salvar-da-troika_-1546409 (accessed 19 March 2019).

Ferrera, M. (2017), 'The Stein Rokkan Lecture 2016: Mission impossible? Reconciling economic and social Europe after the euro crisis and Brexit', European Journal of Political Research, Vol. 56, No. 1, pp. 3-22.

Ferrera, M. (2020), 'Mass democracy, the welfare state and European integration: a neo-Weberian analysis', European Journal of Social Theory, Vol. 23, No. 2, pp. $165-183$.

Field, B. and Botti, A. (2013), Politics and Society in Contemporary Spain: From Zapatero to Rajoy, Palgrave Macmillan, New York.

Financial Crisis Inquiry Commission (2011), Final Report of the National Commission on the Causes of the Financial and Economic Crisis in the United States, Official Government Edition, Washington.

Financial Times (2012), 'Spain seeks Eurozone bailout', Financial Times, 10 June. Fine Gael (2011), Fine Gael Manifesto: Let's Get Ireland Working, Fine Gael, Dublin.

Finke, D. and Bailer, S. (2019), 'Crisis bargaining in the European Union: formal rules or market pressure?', European Union Politics, Vol. 20, No. 1, pp. 109-133.

Finn, C. (2015), 'Why hasn't the USC been scrapped yet?', The Journal, 14 October.

Finn, C. (2016), 'Ireland's much-hated tax that just won't go away: the Universal Social Charge', The Journal, 8 October.

Finn, C. (2019), 'Why hasn't the government merged the PRSI and the USC yet? Minister says it's "complex", The Journal, 30 June.

Fishman, R.M. (2012), 'Anomalies of Spain's economy and economic policy-making', Contributions to Political Economy, Vol. 31, No. 1, pp. 67-76.

Freeman, G.P. (2006), 'National models, policy types, and the politics of immigration in liberal democracies', West European Politics, Vol. 29, No. 2, pp. 227-247.

Freire, A. and Santana-Pereira, J. (2012), 'Economic voting in Portugal, 2002-2009', Electoral Studies, Vol. 31, No. 3, pp. 506-512.

Gago, A. (2016), 'Crisis, EU transformation and union strategies: the impact of conditionality on the strategic repertoire of Spanish trade unions during the Eurozone crisis', Revista Española de Ciencia Política, No. 42, pp. 45-68.

Gago, A. (2018), EU Ordoliberal Intergovernmentalism and the Transformation of National Political Opportunities: Explaining Governments' and Trade Unions' Strategies in Portugal, Spain and Italy during the Eurozone Crisis, PhD Dissertation in Political Science, Università Degli Studi di Milano, Milan. 
Gago, A. and Moury, C. (2018), 'Making and justifying impossible choices: trade unions and three-level games in Ireland and Portugal', unpublished manuscript.

Galasso, V. (2014), 'The role of political partisanship during economic crises', Public Choice, Vol. 158, Nos 1-2, pp. 143-165.

Garea, F. (2011), 'Zapatero convoca el 20-N para que "otro Gobierno dé certidumbre"', El País, 29 July.

Garrett, G. and Tsebelis, G. (1996), 'An institutional critique of intergovernmentalism', International Organization, Vol. 50, No. 2, pp. 269-299.

George, A.L. and Bennett, A. (2005), Case Studies and Theory Development in the Social Sciences, MIT Press, Cambridge, MA.

Georgiadou, V., Kafe, A., Nezi, S. and Pieridis, C. (2019), 'Plebiscitarian spirit in the square: key characteristics of the Greek indignants', International Journal of Politics, Culture, and Society, Vol. 32, No. 1, pp. 43-59.

Gerodimos, R. (2015), 'The ideology of far left populism in Greece: blame, victimhood and revenge in the discourse of Greek anarchists', Political Studies, Vol. 63, No. 3, pp. 608-625.

Giger, N. and Nelson, M. (2011), 'The electoral consequences of welfare state retrenchment: blame avoidance or credit claiming in the era of permanent austerity?', European Journal of Political Research, Vol. 50, No. 1, pp. 1-23.

Gocaj, L. and Meunier, S. (2013), 'Time will tell: the EFSF, the ESM, and the euro crisis', Journal of European Integration, Vol. 35, No. 3, pp. 239-253.

Gopinath, G. (2020), 'The Great Lockdown: worst economic downturn since the Great Depression', IMFBlog, 14 April, available at: https://blogs.imf.org/2020/04/14/ the-great-lockdown-worst-economic-downturn-since-the-great-depression/ (accessed 25 February 2021).

Gotev, G. (2012), 'Cyprus to get bail-out from EU, Russia: president', Euractiv, 5 July, available at: www.euractiv.com/section/euro-finance/news/cyprus-to-getbailout-from-eu-russia-president/ (accessed 24 February 2020).

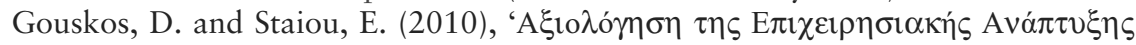

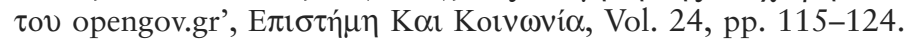

Grande, E. (1996), 'The state and interest groups in a framework of multi-level decision-making: the case of the European Union', Journal of European Public Policy, Vol. 3, No. 3, pp. 318-338.

Graziano, P. (2011), 'Europeanisation and domestic policy change: adapting to the European employment strategy in Italy and France', Governance, Vol. 24, No. 3, pp. 583-605.

Greer, S. (2014), 'Structural adjustment comes to Europe: lessons for the Eurozone from the conditionality debates', Global Social Policy, Vol. 14, No. 1, pp. 51-71.

Guillén, A.M. and León, M. (2011), The Spanish Welfare State in European Context, Ashgate Publishing, Ltd, Farnham.

Gunaydin, H. (2018), 'Who can reform the labor market? IMF conditionality, partisanship, and labor unions', International Interactions, Vol. 44, No. 5, pp. 888-918.

Györffy, D. (2018), Trust and Crisis Management in the European Union, Palgrave Macmillan, Cham.

Ha, E. and Kang, M. (2015), 'Government policy responses to financial crises: identifying patterns and policy origins in developing countries', World Development, Vol. 68, pp. 264-281.

Hall, P.A. (2012), 'The economics and politics of the Euro crisis', German Politics, Vol. 21, No. 4, pp. 355-371. 
Hall, P.A. and Soskice, D. (2001), 'An introduction to varieties of capitalism', in Hall, P.A. and Soskice, D. (eds), Varieties of Capitalism: The Institutional Foundations of Comparative Advantage, Oxford University Press, Oxford, pp. 1-68.

Hallerberg, M. and Basinger, S. (1998), 'Internationalization and changes in tax policy in OECD countries: the importance of domestic veto players', Comparative Political Studies, Vol. 31, No. 3, pp. 321-352.

Hamann, K. (2013), 'The relationship between unions and Zapatero's government: from social pacts to general strike', in Field, B. and Botti, A. (eds), Politics and Society in Contemporary Spain, Palgrave Macmillan, New York, pp. 123-141.

Hardiman, N. and MacCarthaigh, M. (2013), How Governments Retrench in Crisis: The Case of Ireland, UCD Geary Institute Discussion Paper Series No. 15.

Hardiman, N. and MacCarthaigh, M. (2017), 'State retrenchment and administrative reform in Ireland: probing comparative policy paradigms', Journal of Comparative Policy Analysis: Research and Practice, Vol. 19, No. 2, pp. 100-118.

Hardiman, N. and Regan, A. (2013), 'The politics of austerity in Ireland', Intereconomics, Vol. 48, No. 1, pp. 4-32.

Hardiman, N., Blavoukos, S., Dellepiane-Avellaneda, S. and Pagoulatos, G. (2016), 'Austerity in the European periphery: the Irish experience', in Heffernan, E., McHale, J. and Moore-Cherry, N. (eds), Debating Austerity in Ireland: Crisis, Experience and Recovery, Royal Irish Academy, Dublin, pp. 83-99.

Hardiman, N., Spanou, C., Araújo, J.F. and MacCarthaigh, M. (2019), 'Tangling with the Troika: "domestic ownership" as political and administrative engagement in Greece, Ireland, and Portugal', Public Management Review, Vol. 21, No. 9, pp. 1265-1286.

Heimberger, P. (2017), 'Did fiscal consolidation cause the double-dip recession in the euro area?', Review of Keynesian Economics, Vol. 5, No. 3, pp. 439-458.

Heins, E. and de la Porte, C. (2015), The Sovereign Debt Crisis, the EU and Welfare State Reform, Springer, Lisbon.

Hennessy, A. (2017), 'Good samaritans vs. hardliners: the role of credible signalling in Greek bailout negotiations', JCMS: Journal of Common Market Studies, Vol. 55, No. 4, pp. 744-761.

Henning, C.R. (2017), Tangled Governance: International Regime Complexity, the Troika, and the Euro Crisis, Oxford University Press, Oxford.

Héritier, A., Meissner, K.L., Moury, C. and Schoeller, M.G. (2019), European Parliament Ascendant: Parliamentary Strategies of Self-Empowerment in the EU, Palgrave Macmillan, London.

Herszenhorn, D.M. (2020), 'EU leaders back budget reboot for coronavirus recovery', Politico, 24 April.

Hick, R. (2018), 'Enter the Troika: the politics of social security During Ireland's bailout', Journal of Social Policy, Vol. 47, No. 1, pp. 1-20.

Hill, D. (2003), 'Global neo-liberalism, the deformation of education and resistance', Journal for Critical Education Policy Studies, Vol. 1, No. 1, pp. 1-30.

Hodson, D. (2012), 'The Eurozone in 2011', Journal of Common Market Studies, Vol. 50, pp. 178-194.

Hodson, D. (2015), 'Eurozone governance: deflation, Grexit 2.0 and the second coming of Jean-Claude Juncker', Journal of Common Market Studies, Vol. 53, pp. 144-161.

Horwitz, L. and Myant, M. (2015), Spain's Labour Market Reforms: The Road to Employment - Or to Unemployment?, Working Paper No. 2015.03, European Trade Union Institute. 
Howarth, D. and Quaglia, L. (2016), The Political Economy of European Banking Union, Oxford University Press, Oxford.

Huerta, J.P. (2019), 'FROB in the restructuring of the Spanish banking system: where it stands after a decade of activity (2009-2019) and considerations for the Banking Union', Revista de Estabilidad Financiera, Banco de España \& Revista de Estabilidad Financiera, No 36, Spring.

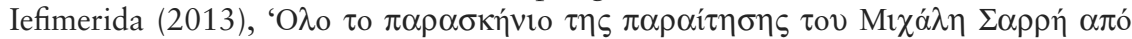

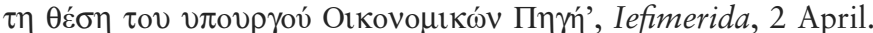

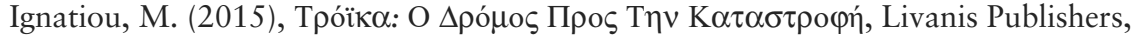
Athens.

Independent Evaluation Office (2003), Annual Report 2003, International Monetary Fund, Washington.

Inman, P. (2016), 'Irish economy surges $26 \%$ as revised figures take in foreign investment', The Guardian, 12 July, available at: www.theguardian.com/business/2016/ jul/12/irish-economic-growth-revised-figures-foreign-investment-aircraft (accessed 19 June 2019).

International Monetary Fund (2009), Greece: Selected Issues, Country Report No. 09/245, International Monetary Fund, Washington.

International Monetary Fund (2010), Spain: 2010 Article IV Consultation IMF, Country Report No. 10/254, International Monetary Fund, Washington.

International Monetary Fund (2011a), Portugal: First Review Under the Extended Arrangement, Country Report No. 11/279, International Monetary Fund, Washington.

International Monetary Fund (2011b), Portugal: Second Review Under the Extended Arrangement, Country Report No. 11/363, International Monetary Fund, Washington.

International Monetary Fund (2011c), Cyprus: Selected Issues Paper, Country Report No. 11/332, International Monetary Fund, Washington.

International Monetary Fund (2011d), Cyprus: Article IV Consultation - Staff Report; Supplement; Public Information Notice on the Executive Board Discussion; and Statement by the Executive Director for Cyprus, Country Report No. 11/331, International Monetary Fund, Washington.

International Monetary Fund (2012a), Greece: First and Second Reviews under the Extended Arrangement Under the Extended Fund Facility, Request for Waiver of Applicability, Modification of Performance Criteria, and Reshaping of Access, Country Report No. 13/20, International Monetary Fund, Washington.

International Monetary Fund (2012b), Article IV and Seventh Review under the Extended Arrangement Staff Report, Country Report No. 12/264, International Monetary Fund, Washington.

International Monetary Fund (2012c), Portugal: Fifth Review Under the Extended Arrangement and Request for Waivers of Applicability and Nonobservance of End-September Performance Criteria, Country Report No. 12/292, International Monetary Fund, Washington.

International Monetary Fund (2012d), Portugal: Fourth Review Under the Extended Arrangement and Request for a Waiver of Applicability of End-June Performance Criteria, Country Report No. 12/179, International Monetary Fund, Washington.

International Monetary Fund (2012e), Portugal: Third Review Under the Extended Arrangement and Request for Waiver of Applicability of End-March Performance Criteria, Country Report No. 12/77, International Monetary Fund, Washington. 
International Monetary Fund (2013a), Greece: First and Second Reviews under the Extended Arrangement Under the Extended Fund Facility, Country Report No. 13/153, International Monetary Fund, Washington.

International Monetary Fund (2013b), Portugal: Eighth and Ninth Reviews Under the Extended Arrangement and Request for Waivers of Applicability of End-September Performance Criteria, Country Report No. 13/324, International Monetary Fund, Washington.

International Monetary Fund (2013c), Portugal: Seventh Review Under the Extended Arrangement and Request for Modification of End-June Performance Criteria, Country Report No. 13/160, International Monetary Fund, Washington.

International Monetary Fund (2013d), Portugal: 2012 Article IV Consultation and Sixth Review Under the Extended Arrangement and Request for Waivers of Applicability of End-December Performance Criteria, Country Report No. 13/18, International Monetary Fund, Washington.

International Monetary Fund (2014a), Portugal: Eleventh Review Under the Extended Arrangement, and Request for Extension of the Arrangement and Waivers of Applicability of End-March Performance Criteria, Country Report No. 14/2012, International Monetary Fund, Washington.

International Monetary Fund (2014b), Portugal: Tenth Review Under the Extended Arrangement and Request for Waivers of Applicability of End-December Performance Criteria, Country Report No. 14/56, International Monetary Fund, Washington.

International Monetary Fund (2017), Portugal: 2017 Article IV Consultation-Press Release; Staff Report; and Statement by the Executive Director for Portugal, Country Report No. 17/278, International Monetary Fund, Washington.

Ivanova, A., Mourmouras, A., Anayotos, G.C. and Mayer, W. (2003), What Determines the Implementation of IMF-Supported Programs?, IMF Working Paper No. 8.

Jensen, C. (2012), 'Two sides of the same coin? Left-wing governments and labour unions as determinants of public spending', Socio-economic Review, Vol. 10, No. 2, pp. 217-240.

Johnston, A. and Regan, A. (2016), 'European monetary integration and the incompatibility of national varieties of capitalism', JCMS: Journal of Common Market Studies, Vol. 54, No. 2, pp. 318-336.

Jordana, J. (2014), 'Multiple crises and policy dismantling in Spain: political strategies and distributive implications', Political Studies Review, Vol. 12, No. 2, pp. 224-238.

Juwana, H. (2005), 'Reform of economic laws and its effects on the post-crisis Indonesian economy', The Developing Economies, Vol. 43, No. 1, pp. 72-90.

Karamichas, J. (2009), 'The December 2008 riots in Greece: profile', Social Movement Studies, Vol. 8, No. 3, pp. 289-293.

Kasperskaya, Y. and Xifré, R. (2019), 'Reform or resist? The tale of two fiscal reforms in Spain after the crisis', Public Money and Management, Vol. 39, No. 7, pp. 494-502.

Katsourides, Y. (2019), 'The Cypriot left and the crisis: one step forward, two steps back', in Holmes, M. and Roder, K. (eds), The European Left and the Financial Crisis, Manchester University Press, Manchester, pp. 86-101.

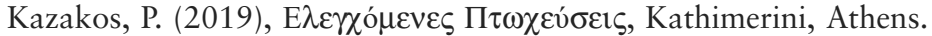

Keaney, M. (2001), 'Consensus by diktat: Washington, London, and the "modernization” of modernization', Capitalism Nature Socialism, Vol. 12, No. 3, pp. 44-70.

Keohane, R.O. and Nye, J.S. (1977), Power and Interdependence: World Politics in Transition, Little, Brown, Boston. 
Ker-Lindsay, J. (2006), 'Presidential power and authority in the Republic of Cyprus', Mediterranean Politics, Vol. 11, No. 1, pp. 21-37.

Khan, M.S. and Sharma, S. (2001), 'IMF conditionality and country ownership of programs', IMF Working Paper, Vol. 01, No. 142.

Khenkin, S. (2016), 'Sistema político de España: transformación radical', Iberoamerica, No. 1, pp. 99-116.

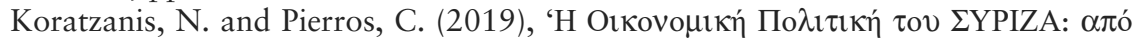

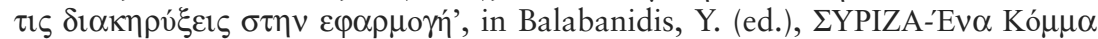

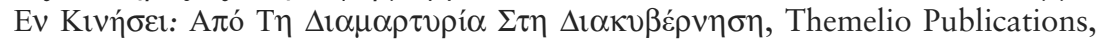
Athens, pp. 227-250.

Kotsi, A., Athanasiou, E., Kanellopoulos, N., Karagianni, R. and Katselidis, I. (2016),

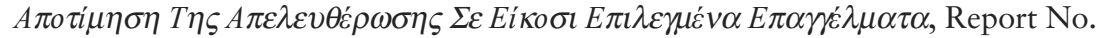
73, KEPE, Athens.

Krugman P. (1993), 'Lessons from Massachusetts for EMU', in Torres, F. and Giavazzi, F. (eds), Adjustment and Growth in the European Monetary Union, CEPR and Cambridge University Press, London, pp. 241-261.

Kutter, A. (2014), 'A catalytic moment: the Greek crisis in the German financial press', Discourse and Society, Vol. 25, No. 4, pp. 446-466.

La Opinión (2011), 'Merkel pide "sin demora” más recortes a Rajoy', La Opinión, 23 November.

La Vanguardia (2010), 'España presenta mañana plan de austeridad', La Vanguardia, 16 May.

Labour (2011), Electoral Manifesto, Labour, Dublin.

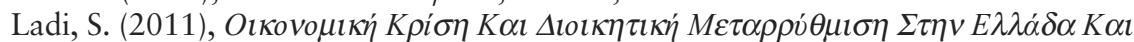

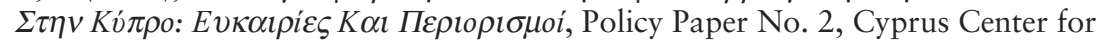
European and International Affairs, University of Nicosia, Nicosia.

Ladi, S. (2014), 'Austerity politics and administrative reform: the Eurozone crisis and its impact upon Greek public administration', Comparative European Politics, Vol. 12, No. 2, pp. 184-208.

Ladi, S. and Graziano, P.R. (2014), “"Fast-forward” Europeanization: welfare state reform in light of the Eurozone crisis', in Coman, R., Kostera, T. and Tomini, L. (eds), Europeanization and European Integration: From Incremental to Structural Change, Palgrave Macmillan, London, pp. 108-126.

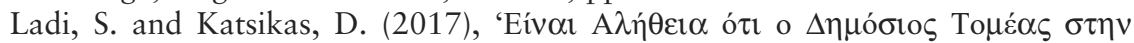

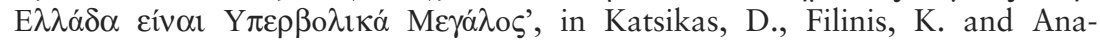

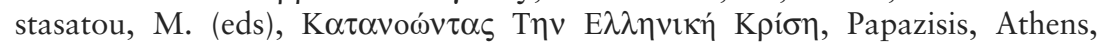
pp. 79-101.

Ladi, S. and Tsagkroni, V. (2019), 'Analysing crisis parliamentary discourse in Greece: whom should we blame?', JCMS: Journal of Common Market Studies, Vol. 57, No. 4, pp. 729-748.

Ladi, S. and Tsarouhas, D. (2014), 'The politics of austerity and public policy reform in the EU', Political Studies Review, Vol. 12, No. 2, pp. 171-180.

Laffan, B. (2012), 'European Union and Eurozone: how to co-exist?', in Allen, F., Carletti, E. and Simonelli, S. (eds), Governance for the Eurozone: Integration or Disintegration?, FIC Press, Philadelphia, pp. 173-188.

Laffan, B. (2016), 'International actors and agencies', in Roche, W.K., O'Connell, P.J. and Prothero, A. (eds), Austerity and Recovery in Ireland: Europe's Poster Child and the Great Recession, Oxford University Press, Oxford, pp. 177-193.

Lafont, I. (2012), 'Los mercados castigan las dudas ante el rescate y las elecciones catalanas', El País, 26 September. 
Leach, W.D. and Sabatier, P.A. (2005), 'To trust an adversary: integrating rational and psychological models of collaborative policymaking', American Political Science Review, Vol. 99, No. 4, pp. 491-503.

León, M., Pavolini, E. and Guillén, A.M. (2015), 'Welfare rescaling in Italy and Spain: political strategies to deal with harsh austerity', European Journal of Social Security, Vol. 17, No. 2, pp. 182-201.

Levitz, P. and Pop-Eleches, G. (2010), 'Why no backsliding? The European Union's impact on democracy and governance before and after accession', Vol. 43, No. 4, pp. 457-485.

Lindvall, J. (2017), Reform Capacity, Oxford University Press, Oxford.

Lipsmeyer, C.S. (2011), 'Booms and busts: how parliamentary governments and economic context influence welfare policy', International Studies Quarterly, Vol. 55, No. 4, pp. 959-980.

Lisi, M. (2010), 'The democratisation of party leadership selection: the Portuguese experience', Portuguese Journal of Social Science, Vol. 9, No. 2, pp. 127-149.

Lisi, M. (2016), 'U-turn: the Portuguese radical left from marginality to government support', South European Society and Politics, Vol. 21, No. 4, pp. 541-560.

Lobo, M.C. and Lewis-Beck, M.S. (2012), 'The integration hypothesis: how the European Union shapes economic voting', Electoral Studies, Vol. 31, No. 3, pp. 522-528.

Lombardi, D. and Woods, N. (2008), 'The politics of influence: an analysis of IMF surveillance', Review of International Political Economy, Vol. 15, No. 5, pp. 711-739.

Lowi, T.J. (1964), 'American business, public policy, case-studies, and political theory', World Politics, Vol. 16, No. 4, pp. 677-715.

Lucas, B. (2012), 'Las 14 claves de la reforma educativa de Wert', Eldiario. Es, 13 December, available at: www.eldiario.es/sociedad/ley-afecta-modelolinguistico_1_5527106.html (accessed 5 March 2021).

Lütz, S. and Kranke, M. (2014), 'The European rescue of the Washington Consensus? EU and IMF lending to Central and Eastern European countries', Review of International Political Economy, Vol. 21, No. 2, pp. 310-338.

Lütz, S., Hilgers, S. and Schneider, S. (2019), 'Games borrower governments play: the implementation of economic adjustment programmes in Cyprus and Portugal', West European Politics, Vol. 42, No. 7, pp. 1443-1463.

Lütz, S., Hilgers, S. and Schneider, S. (2020), 'When numbers don't add up: bureaucratic culture and conflicts in EU-IMF programs', in Chang, M., Steinberg, F. and Torres, F. (eds), The Political Economy of Adjustment Throughout and Beyond the Eurozone Crisis, Routledge, Abingdon and New York, pp. 38-58.

MacCarthaigh, M. and Hardiman, N. (2020), 'Exploiting conditionality: EU and international actors and post-NPM reform in Ireland', Public Policy and Administration, Vol. 35, No. 2, pp. 179-200.

Magalhães, P.C. (2013), 'O partido dos pensionistas', Personal Blog, 8 May, available at: www.pedro-magalhaes.org/o-partido-dos-pensionistas/ (accessed 31 October 2018).

Mair, P. (2009), Representative versus Responsible Government, Working Paper, 9 August, Max Plank Institute for the Study of Societies, Cologne.

Mandelkern, R. and Koreh, M. (2018), 'Interrupting gradual institutional change: how "continuity agents" have stalled and even reversed gradual welfare-state reforms in Israel', Journal of European Public Policy, Vol. 25, No. 11, pp. 1706-1725.

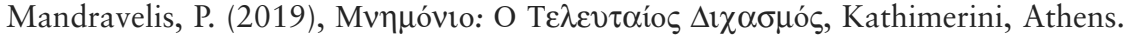


Martin, I.W. and Gabay, N. (2018), 'Tax policy and tax protest in 20 rich democracies, 1980-2010', British Journal of Sociology, Vol. 69, No. 3, pp. 647-669.

Martín, L.A.B., Nieto, M.J.B., Herrero, G.A.G. and Navarro, J.M.R. (2013), 'Informe sobre el desarrollo y evaluación territorial de la ley de promoción de la autonomía personal y atención a las personas en situación de dependencia', Observatorio Estatal de La Dependencia, available at: https:/consaludmental.org/publicaciones/ XDictamenObservatorioDependencia.pdf (accessed 1 March 2021).

Matthijs, M. and McNamara, K. (2015), 'The euro crisis' theory effect: northern saints, southern sinners, and the demise of the eurobond', Journal of European Integration, Vol. 37, No. 2, pp. 229-245.

McDonald, H. (2016), 'Ireland set for minority government after two main parties reach deal', Guardian, 29 April, available at: www.theguardian.com/business/2016/ jul/12/irish-economic-growth-revised-figures-foreign-investment-aircraft (accessed 5 March 2021).

McManus, I.P. (2018), 'Political parties as drivers of post-crisis social spending in liberal welfare states', Comparative European Politics, Vol. 16, No. 5, pp. 843-870.

Meissner, K.L. and McKenzie, L. (2019), 'The paradox of human rights conditionality in EU trade policy: when strategic interests drive policy outcomes', Journal of European Public Policy, Vol. 26, No. 9, pp. 1273-1291.

Mendizabal, N.C. (2014), 'Crisis management, re-centralization and the politics of austerity in Spain', International Journal of Iberian Studies, Vol. 27, No. 1, pp. 3-20.

Meunier, S. (2000), 'What single voice? European institutions and EU-U.S. trade negotiations', International Organization, Vol. 54, No. 1, pp. 103-135.

Michaelides, A. (2014), 'Cyprus: from boom to bail-in', Economic Policy, Vol. 29, No. 80, pp. 639-689.

Michalopoulos, S. (2020), 'Nine member states ask for eurobonds to face coronavirus crisis', Euractiv, 25 March, available at: www.euractiv.com/section/economy-jobs/ news/nine-member-states-ask-for-eurobonds-to-face-coronavirus-crisis/ (accessed 5 March 2021).

Ministry of Finance (2010), Update of the Hellenic Stability and Growth Programme, No. Ares(2010)23198, Athens.

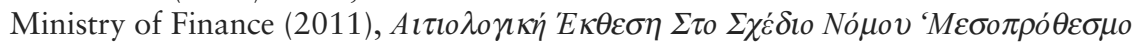

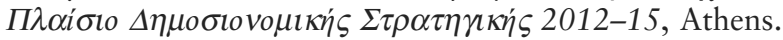

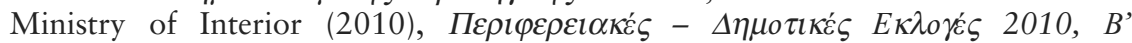

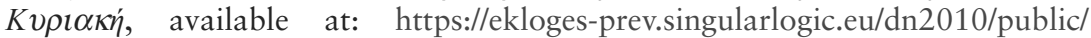
index.html\#\{\%22page\%22:\%22main \%22\} (accessed 29 January 2020).

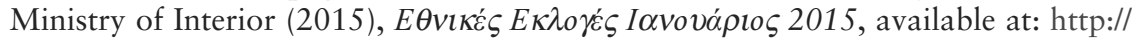
ekloges-prev.singularlogic.eu/v2015a/v/public/index.html\#\{\%22cls\%22:\%22mai n\%22,\%22params\%22:\{\}\} (accessed 4 February 2020).

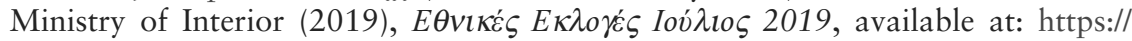
ekloges.ypes.gr/current/v/home/ (accessed 10 February 2020).

Mody, A. (2014), 'The ghost of Deauville', VOX CEPR Policy Portal, 7 January, available at: https://voxeu.org/article/ghost-deauville (accessed 7 June 2019).

Molina, O. and Godino, A. (2013), 'Economic reforms and the labor market: Zapatero's endless period in the wilderness', in Field, B. and Botti, A. (eds), Politics and Society in Contemporary Spain, Palgrave Macmillan, New York, pp. 101-121.

Moravcsik, A. (1994), 'Why the European Union strengthens the state: domestic politics and international cooperation', CES Working Paper, No. 52, available at: http://aei.pitt.edu/9151/1/Moravcsik52.pdf (accessed 1 March 2021). 
Morlino, L. and Sottilotta, C.E. (2019), The Politics of the Eurozone Crisis in Southern Europe: A Comparative Reappraisal, Palgrave Macmillan, Switzerland.

Moschella, M. (2016), 'Negotiating Greece: layering, insulation, and the design of adjustment programs in the Eurozone', Review of International Political Economy, Vol. 23, No. 5, pp. 799-824.

Moschella, M. (2017), 'When some are more equal than others: national parliaments and intergovernmental bailout negotiations in the Eurozone', Government and Opposition, Vol. 52, No. 2, pp. 239-265.

Moury, C. (2013), Coalition Government and Party Mandate: How Coalition Agreements Constrain Ministerial Action, Routledge, Abingdon and New York.

Moury, C. and Afonso, A. (2019), 'Beyond conditionality: policy reversals in Southern Europe in the aftermath of the Eurozone crisis', South European Society and Politics, Vol. 24, No. 2, pp. 155-176.

Moury, C. and Freire, A. (2013), 'Austerity policies and politics: the case of Portugal', Pôle Sud, No. 2, pp. 35-56.

Moury, C. and Standring, A. (2017), "Going beyond the Troika": power and discourse in Portuguese austerity politics', European Journal of Political Research, Vol. 56, No. 3, pp. 660-679.

Moury, C., Cardoso, D. and Gago, A. (2019), 'When the lenders leave town: veto players, electoral calculations and vested interests as determinants of policy reversals in Spain and Portugal', South European Society and Politics, Vol. 24, No. 2, pp. 177-204.

Moury, C., de Giorgi, E. and Pita Barros, P. (2021), 'How to combine public spending with fiscal rigor? "Austerity by stealth" in post-bailout Portugal (2015-2019)', South European Society and Politics, 1-28.

Mulas-Granados, C. (2003), 'The political and economic determinants of budgetary consolidation in Europe', European Political Economy Review, Vol. 1, No. 1, pp. 015-039.

Muro, D. (2015), 'When do countries re-centralize? Ideology and party politics in the age of austerity', in Gillespie, R. and Gray, C. (eds), Contesting Spain? The Dynamics of Nationalist Movements in Catalonia and the Basque Country, Routledge, London, pp. 22-40.

Murphy, M.P. (2014), 'Ireland: Celtic tiger in austerity - explaining Irish path dependency', Journal of Contemporary European Studies, Vol. 22, No. 2, pp. 132-142.

Mylonas, H. (2016), 'Greece', European Journal of Political Research Political Data Yearbook, Vol. 55, pp. 113-123.

National Herald (2020), 'Greek High Court reviewing retroactive pensions, holiday bonuses', National Herald, 10 February, available at: www. thenationalherald.com/278978/greek-high-court-reviewing-retroactive-pensionsholiday-bonuses/ (accessed 10 February 2020).

Nelson, S.C. (2014), 'Playing favorites: how shared beliefs shape the IMF's lending decisions', International Organization, Vol. 68, No. 2, pp. 297-328.

Newstalk (2017), 'Enda Kenny: the promises versus reality', Newstalk, 18 May, available at: www.newstalk.com/news/enda-kenny-the-promises-vs-the-reality-535583 (accessed 19 May 2019).

Nölke, A. (2016), 'Economic causes of the Eurozone crisis: the analytical contribution of Comparative Capitalism', Socio-economic Review, Vol. 14, No. 1, pp. 141-161.

Nooruddin, I. and Simmons, J.W. (2006), 'The politics of hard choices: IMF programs and government spending', International Organization, Vol. 60, No. 4, pp. 1001-1033. 
Nugent, C. (2018), 'The Irish construction sector (2008-2016) - employment, compensation and labour costs', NERI Research InBrief, NERI-Nevin Economic Research Institute, No. 59.

Offe, C. (2017), 'Narratives of responsibility: German politics in the Greek debt crisis', in Castells, M., Bouin, O., Caraça, J., Cardoso, G., Thompson, Jo.B. and Wieviorka, M. (eds), Europe's Crises, Polity Press, Cambridge, pp. 269-293.

Oireachtas (2016), Report of the Joint Committee of Inquiry into the Banking Crisis, Oireachtas, Dublin.

Organisation for Economic Co-operation and Development (2009), OECD Economic Surveys: Ireland. Volume 17/2009, OECD, Paris.

Organisation for Economic Co-operation and Development (2014), Going for Growth Spain, Interim report, OECD, Paris.

Orphanides, A. (2013), 'The sovereign debt crisis in the Euro Area', Ekonomia, Vol. 15, No. 2, pp. 45-64.

Orphanides, A. (2014), What Happened in Cyprus? The Economic Consequences of the Last Communist Government in Europe, LSE Financial Markets Group Special Papers Series.

Orriols, L. and Cordero, G. (2016), 'The breakdown of the Spanish two-party system: the upsurge of Podemos and Ciudadanos in the 2015 general election', South European Society and Politics, Vol. 21, No. 4, pp. 469-492.

Otxoa, I. (2007), El Recorte de Derechos En Las Reformas Laborales, Manu Robles-Arangiz Institutua, Bilbau.

Pagoulatos, G. (2018), Greece after the Bailouts: Assessment of a Qualified Failure, GreeSE Paper No. 130, Hellenic Observatory, LSE, London.

Panayi, E. and Zenios, S.A. (2015), 'Was the Cyprus crisis banking or sovereign debt?', Journal of Banks and Bank Systems, Vol. 10, No. 2, pp. 23-34.

Papakonstantinou, G. (2016), Game Over: The Inside Story of the Greek Crisis, CreateSpace Independent Publishing Platform, Athens.

Papandreou, G. (2015), 'Reflections on the Greek and Eurozone crisis: a view from the inside', in Karyotis, G. and Gerodimos, R. (eds), The Politics of Extreme Austerity: Greece in the Eurozone Crisis, Springer, Basingstoke, pp. 240-258.

Papathanasiou, Y. (2017), 8 Míves, Livanis Publishers, Athens.

Parker, O. and Tsarouhas, D. (2018), 'Causes and consequences of crisis in the Eurozone periphery', in Parker, O. and Tsarouhas, D. (eds), Crisis in the Eurozone Periphery: The Political Economies of Greece, Spain, Portugal and Ireland, Palgrave Macmillan, London, pp. 1-28.

Partido Popular (2011), Lo Que España Necesita: Programa Electoral Del PP, Partido Popular, Spain.

PASOK (2009), PASOK Election Programme, PASOK, Athens.

Patashnik, E.M. (2014), Reforms at Risk: What Happens after Major Policy Changes Are Enacted, Vol. 136, Princeton University Press, Princeton and Oxford.

Pegasiou, A. (2013), 'The Cypriot economic collapse: more than a conventional South European failure', Mediterranean Politics, Vol. 18, No. 3, pp. 333-351.

Pegasiou, A. (2018), 'EU coordination in Cyprus', in Ragone, S. (ed.), Managing the Euro Crisis, Routledge, Abingdon and New York, pp. 83-102.

Pérez, C. (2012a), 'Draghi cree que el Gobierno actuó de "la peor manera posible" con Bankia', El País, 31 May.

Pérez, C. (2012b), 'Pulso entre Madrid y Bruselas por la revalorización de las pensiones', El País, 6 October. 
Pérez, C. (2014), 'Bruselas avisa a España de los “desafíos” tras el rescate y reclama seguir los ajustes', El País, 22 January.

Pérez, C. and Doncel, L. (2012), 'España pide un rescate de hasta 100.000 millones para la banca', El País, 10 June.

Perez, S.A. and Matsaganis, M. (2018), 'The political economy of austerity in Southern Europe', New Political Economy, Vol. 23, No. 2, pp. 192-207.

Perez, S.A. and Matsaganis, M. (2019), 'Export or perish: can internal devaluation create enough good jobs in Southern Europe?', South European Society and Politics, Vol. 24, No. 2, pp. 259-285.

Pianta, M. (2013), 'Democracy lost: the financial crisis in Europe and the role of civil society', Journal of Civil Society, Vol. 9, No. 2, pp. 148-161.

Picot, G. and Tassinari, A. (2017), 'All of one kind? Labour market reforms under austerity in Italy and Spain', Socio-economic Review, Vol. 15, No. 2, pp. 461-482.

PIMCO (2013), Independent Due Diligence of the Banking System of Cyprus, PIMCO, London.

Pires, L.R. and Martins, N. (2015), Segredos de Estado, Matéria Prima Edições, Lisbon.

Pochet, P. (1999), 'Monetary union and collective bargaining in Belgium', in Pochet, P. (ed.), Monetary Union and Collective Bargaining in Europe, P.I.E.-Peter Lang, Brussels, pp. 187-218.

Pop, V. (2012), 'EU monitors heading to Madrid, despite "Men in Black" claims', Euobserver.Com, 12 June, available at: https://euobserver.com/economic/116575 (accessed 1 March 2021).

Pop-Eleches, G. (2008), From Economic Crisis to Reform: IMF Programs in Latin America and Eastern Europe, Princeton University Press, Princeton.

Prandeka, M. (2013), Portugal: Labour Market Reforms - A Summary of Main Problems and Actions Taken, Global and Economic Market Outlook, Eurobank Research, available at: www.eurobank.gr/Uploads/Reports/56_FOCUS_NOTES_ PORTUGAL_LABOUR_MARKET_REFORMS.pdf (accessed 21 March 2019).

Preston, P. and Silke, H. (2014), 'Ireland - from neoliberal champion to "the eye of the storm"', Javnost-the Public, Vol. 21, No. 4, pp. 5-23.

Psylides, G. (2019), 'Supreme Court reserves judgement on civil service pay cuts', 1 November, available at: https://cyprus-mail.com/2019/11/01/supreme-courtreserves-judgement-on-civil-service-pay-cuts/ (accessed 26 February 2020).

Putnam, R.D. (1988), 'Diplomacy and domestic politics: the logic of two-level games', International Organization, Vol. 42, No. 3, pp. 427-460.

Radaelli, C.M. (2003), 'The Europeanization of public policy', in Featherstone, K. and Radaelli, C. (eds), The Politics of Europeanization, Vol. 320, Oxford University Press, Oxford and New York, pp. 27-56.

Reforms for the Completion of the Current Programme and Beyond (undated), Wall Street Journal, available at: https://online.wsj.com/public/resources/documents/ reform.pdf (accessed 5 February 2020).

Regan, A. (2013), The Impact of the Eurozone Crisis on Irish Social Partnership: A Political Economy Analysis, DIALOGUE Working Paper No. 3.

Regan, A. (2017), 'Post-crisis social dialogue and economic governance in Ireland', in Guardiancich, I. and Molina, O. (eds), Talking Through the Crisis: Social Dialogue and Industrial Relations Trends in Selected EU Countries, International Labour Organization, Geneva.

Rehn, O. (2020), Walking the Highwire: Rebalancing the European Economy in Crisis, Palgrave Macmillan, London. 
Remmer, K.L. (1986), 'The politics of economic stabilization: IMF standby programs in Latin America, 1954-1984', Comparative Politics, Vol. 19, No. 1, pp. 1-24.

Republic of Cyprus (2012), Annual Report 2011: Public Debt Management, Ministry of Finance, Nicosia.

Reuters (2012), 'Market door closed to Spain: Treasury minister', Reuters, 5 June.

Riain, S.Ó. (2014), The Rise and Fall of Ireland's Celtic Tiger: Liberalism, Boom and Bust, Cambridge University Press, Cambridge.

Rickard, S.J. and Caraway, T.L. (2019), 'International demands for austerity: examining the impact of the IMF on the public sector', Review of International Organizations, Vol. 14, No. 1, pp. 35-57.

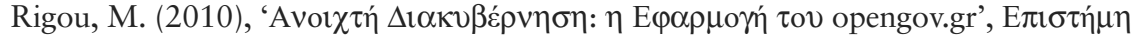

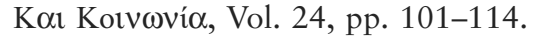

Robbins, G. and Lapsley, I. (2014), 'The success story of the Eurozone crisis? Ireland's austerity measures', Public Money and Management, Vol. 34, No. 2, pp. 91-98.

Rodon, T. and Hierro, M.J. (2016), 'Podemos and Ciudadanos shake up the Spanish party system: the 2015 local and regional elections', South European Society and Politics, Vol. 21, No. 3, pp. 339-357.

Rodrigues, S. (2017), 'Quando Paulo Portas revogou o irrevogável', Público, 30 August.

Rodrik, D. (1998), 'Has globalization gone too far?', Challenge, Vol. 41, No. 2, pp. 81-94.

Rodrik, D., Easterly, W. and Krueger, A.O. (1999), 'Governing the global economy: does one architectural style fit all? [with comments and discussion]', Brookings Trade Forum, pp. 105-139.

Rogers, C. (2009), 'From social contract to "social contrick": the depoliticisation of economic policy-making under Harold Wilson, 1974-75', British Journal of Politics and International Relations, Vol. 11, No. 4, pp. 634-651.

Romero, A. (2020), 'Los cinco puntos esenciales de la reforma de las pensiones que el Congreso quiere cerrar este año', Público, 4 March.

Rommerskirchen, C. (2015), 'Debt and punishment: market discipline in the Eurozone', New Political Economy, Vol. 20, No. 5, pp. 752-782.

Rori, L. (2016), 'The 2015 Greek parliamentary elections: from great expectations to no expectations', West European Politics, Vol. 39, No. 6, pp. 1323-1343.

Ross, F. (2000), "'Beyond left and right": the new partisan politics of welfare', Governance, Vol. 13, No. 2, pp. 155-183.

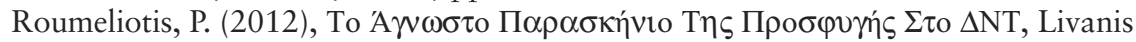
Publishers, Athens.

Royo, S. (2013), 'How did the Spanish financial system survive the first stage of the global crisis?', Governance, Vol. 26, No. 4, pp. 631-656.

Ryan, P. (2015), 'Fianna Fáil planned water charges before Troika bailout', Independent. $I e, 19$ October, available at: www.independent.ie/irish-news/water/irish-water-crisis/ fianna-fail-planned-water-charges-before-Troika-bailout-34120454.html (accessed 5 March 2021).

Sacchi, S. (2018), 'The Italian welfare state in the crisis: learning to adjust?', South European Society and Politics, Vol. 23, No. 1, pp. 29-46.

Santos Pereira, Á. (2014), Reformar Sem Medo, Gradiva, Lisbon.

Sarmento, J.M. (2018), 'Um orçamento a pensar nas eleições', ECO, 16 October, available at: https://eco.sapo.pt/especiais/analise-do-porta-voz-do-psd-para-asfinancas-este-e-um-orcamento-a-pensar-nas-eleicoes-diz-joaquim-miranda-sarmento (accessed 30 October 2019). 
Schäfer, A., Schnabel, I. and di Mauro, B.W. (2017), Expecting Bail-In? Evidence from European Banks, CEPR Discussion Paper No. 11061.

Schelling, T.C. (1980), The Strategy of Conflict, Harvard University Press, Cambridge and London.

Schimmelfennig, F. (2015), 'Liberal intergovernmentalism and the Euro Area crisis', Journal of European Public Policy, Vol. 22, No. 2, pp. 177-195.

Schmidt, V.A. (2002), The Futures of European Capitalism, Oxford University Press, Oxford.

Schmidt, V.A. (2016), "Reinterpreting the rules "by stealth" in times of crisis: a discursive institutionalist analysis of the European Central Bank and the European Commission', West European Politics, Vol. 39, No. 5, pp. 1032-1052.

Sedelmeier, U. (2012), 'Is Europeanisation through conditionality sustainable? Lock-in of institutional change after EU accession', West European Politics, Vol. 35, No. 1, pp. 20-38.

Sérvulo González, J. and Garea, F. (2012), 'El Gobierno admite que necesita ayuda europea para sanear la banca', El País, 5 June.

Séville, A. (2017), 'From "one right way" to "one ruinous way"? Discursive shifts in "There is no alternative", European Political Science Review, Vol. 9, No. 3, pp. 449-470.

Smith, H. and Rushe, D. (2011), 'Greek government on brink as referendum call triggers market slump', Guardian, 1 January, available at: www.theguardian.com/ business/2011/nov/01/greek-government-brink-markets-slump (accessed 26 March 2020).

Smyth, J. (2011), 'Welfare and child benefit cuts effective from today', Irish Times, 3 January, available at: www.irishtimes.com/news/welfare-and-child-benefit-cutseffective-from-today-1.1081599 (accessed 8 June 2020).

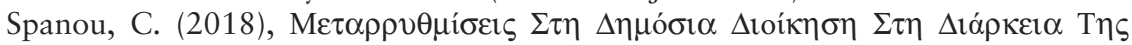
Kpíons, ELIAMEP and Papazisis Publishers, Athens.

Spiegel Online (2012), 'Spain bailout "Won't buoy sentiment for long”, Spiegel Online, 11 June, available at: www.spiegel.de/international/europe/german-presscommentaries-on-eu-bailout-of-spanish-banks-a-838150.html (accessed 3 March 2021).

Spiegel, P. (2015), 'Tsipras letter to Merkel: the annotated text', Financial Times, 22 March, available at: www.ft.com/content/59ff87f1-00fe-3766-8b15-3cdade247bdd (accessed 15 March 2019).

Starke, P., Kaasch, A. and Van Hooren, F. (2013), The Welfare State as Crisis Manager: Explaining the Diversity of Policy Responses to Economic Crisis, Palgrave Macmillan, Basingstoke.

Stockhammer, E. (2016) 'Neoliberal growth models, monetary union and the Euro crisis: a post-Keynesian perspective', New Political Economy, Vol. 21, No. 4, pp. 365-379.

Stolfi, F. and Papamakariou, N. (2019), 'Border clashes: the distributive politics of professional liberalisation in Greece, 2010-2018', Journal of Public Policy, Vol. 41, No. 1, pp. 90-110.

Streeck, W. (2014), Buying Time: The Delayed Crisis of Democratic Capitalism, Verso Books, London.

Stubbs, T., Kentikelenis, A., Stuckler, D., McKee, M. and King, L. (2017), 'The impact of IMF conditionality on government health expenditure: a cross-national analysis of 16 West African nations', Social Science and Medicine, Vol. 174, pp. 220-227. 
Tallberg, J. (2008), 'Bargaining power in the European Council', JCMS: Journal of Common Market Studies, Vol. 46, No. 3, pp. 685-708.

Tavares, J. (2004), 'Does right or left matter? Cabinets, credibility and fiscal adjustments', Journal of Public Economics, Vol. 88, No. 12, pp. 2447-2468.

Távora, I. and González, P. (2014), The Reform of Joint Regulation and Labour Market Policy during the Current Crisis: National Report on Portugal, European Trade Union Institute, Brussels.

Taylor-Gooby, P., Leruth, B. and Chung, H. (2017), After Austerity: Welfare State Transformation in Europe after the Great Recession, Oxford University Press, Oxford.

Thomsen, P. (2019), 'The IMF and the Greek crisis: myths and realities', London School of Economics, 30 September, available at: www.imf.org/en/News/ Articles/2019/10/01/sp093019-The-IMF-and-the-Greek-Crisis-Myths-and-Realities (accessed 18 June 2020).

Thomson, R., Royed, T., Naurin, E., Artés, J., Costello, R., Ennser-Jedenastik, L., Ferguson, M., et al. (2017), 'The fulfillment of parties' election pledges: a comparative study on the impact of power sharing', American Journal of Political Science, Vol. 61, No. 3, pp. 527-542.

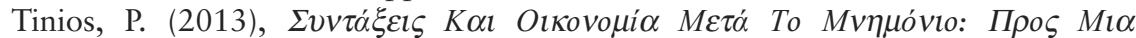

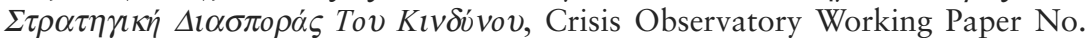
1, ELIAMEP, Athens, available at: https://crisisobs.gr/2013/04/\%cf\% 80\%ce \%bb $\%$ ce $\%$ ac $\%$ cf $\% 84 \%$ cf\% $89 \%$ ce $\%$ bd- $\%$ cf $\% 84 \%$ ce $\%$ ae $\%$ ce $\%$ bd $\%$ ce $\%$ b9 $\%$ ce $\%$ bf $\%$ cf\% $82 /$ (accessed 5 March 2021).

Tooze, A. (2018), Crashed: How a Decade of Financial Crises Changed the World, Penguin, London.

Torres, A.A. (2014), 'Las cajas de ahorros españolas: una crisis de solvencia', ODEON, No. 8, pp. 189-221.

Triga, V. (2017), 'Parties and change in the post-bailout Cyprus: the May 2016 parliamentary elections', South European Society and Politics, Vol. 22, No. 2, pp. 261-279.

Tsebelis, G. (2016), 'Lessons from the Greek crisis', Journal of European Public Policy, Vol. 23, No. 1, pp. 25-41.

Tsekos, T.N. and Hlepas, N.K. (2019), 'Greek municipalities before and during the austerity era: imposed policies, local resistance and unsuccessful reforms', in Lippi, A. and Tsekos, T.N. (eds), Local Public Services in Times of Austerity across Mediterranean Europe, Palgrave Macmillan, Cham, pp. 49-71.

Tzifakis, N. (2019), 'What the ratification of the Prespa Agreement means for Greek politics', EUROPP Blog LSE, 30 January, available at: https://blogs.lse.ac.uk/ europpblog/2019/01/30/what-the-ratification-of-the-prespa-agreement-means-forgreek-politics (accessed 2 June 2020).

Van Der Heijden, M., Beetsma, R. and Romp, W. (2018), “Whatever it takes” and the role of Eurozone news', Applied Economics Letters, Vol. 25, No. 16, pp. 1166-1169.

Varoufakis, Y. (2017), Adults in the Room: My Battle with Europe's Deep Establishment, The Bodley Head, London.

Vreeland, J.R. (1999), 'The IMF: lender of last resort or scapegoat', Prepared for the International Studies Association Conference, Omni Shoreham Hotel, Washington, DC, February 16-21.

Vreeland, J.R. (2004), The International and Domestic Politics of IMF Programs, Paper prepared for the Reinventing Bretton Woods Committee and World Economic 
Forum conference on The Fund's Role in Emerging Markets: Reassessing the Adequacy of its Resources and Lending Facilities. Amsterdam, 18-19 November, De Nederlandsche Bank, Westeinde 1.

Walter, S. (2016), 'Crisis politics in Europe: why austerity is easier to implement in some countries than in others', Comparative Political Studies, Vol. 49, No. 7, pp. 841-873.

Warlouzet, L. (2019), 'The EEC/EU as an evolving compromise between French dirigism and German ordoliberalism (1957-1995)', JCMS: Journal of Common Market Studies, Vol. 57, No. 1, pp. 77-93.

Wearden, G. (2010), 'Greece debt crisis: timeline', The Guardian, 5 May.

Wildasin, D.E. (1999), 'Externalities and bailouts: hard and soft budget constraints in intergovernmental fiscal relations', 25 June, The World Bank Policy Research Working Paper, available at: https://doi.org/10.1596/1813-9450-1843 (accessed 11 October 2019).

Wilson, J.Q. (1980), The Politics of Regulation, Basic Books, New York.

Xiouros, C. (2016), 'Handling of the Laiki Bank ELA and the Cyprus bail-in package', in Michaelides, A. and Orphanides, A. (eds), The Cyprus Bail-In: Policy Lessons from the Cyprus Economic Crisis, Imperial College Press, London, pp. 33-102.

Young, B. (2014), 'German ordoliberalism as agenda setter for the euro crisis: myth trumps reality', Journal of Contemporary European Studies, Vol. 22, No. 3, pp. 276-287.

Young, E. (2013), 'Russian money in Cyprus: why is there so much?', BBC, 18 March, available at: www.bbc.co.uk/news/business-21831943 (accessed 24 February 2020).

Zahariadis, N. (2013), 'Leading reform amidst transboundary crises: lessons from Greece', Public Administration, Vol. 91, No. 3, pp. 648-662.

Zahariadis, N. (2016), 'Powering over puzzling? Downsizing the public sector during the Greek sovereign debt crisis', Journal of Comparative Policy Analysis: Research and Practice, Vol. 18, No. 5, pp. 464-478.

Zapatero, J.L.R. (2011), Reply to the ECB Letter, 6 August, available at: www. ecb.europa.eu/ecb/access_to_documents/document/correspondence/shared/data/ ecb.dr.cor20110806Zapatero_reply.en.pdf (accessed 1 March 2021).

Zapatero, J.L.R. (2013), El Dilema: 600 Días de Vértigo, Grupo Planeta (GBS), Barcelona. 